\title{
Gambaran Keluhan Muskuloskeletal pada Latihan Beban di Pusat Kebugaran Body Fitness 2017
}

\author{
Jason Julio Sutanto ${ }^{1}$, Handy Winata ${ }^{2}$, Santoso Gunardi ${ }^{2}$ \\ ${ }^{1}$ Mahasiswa Fakultas Kedokteran Universitas Kristen Krida Wacana \\ ${ }^{2}$ Staf Pengajar Bagian Anatomi, Fakultas Kedokteran Universitas Kristen Krida Wacana \\ Jalan Arjuna Utara Nomo 6, Jakarta 11510 \\ Alamat Koresponden: han_dy19@yahoo.com
}

\begin{abstract}
Abstrak
Latihan beban merupakan latihan fisik yang dapat membantu meningkatkan daya tahan dan kekuatan otot. Selain menjadi lebih kuat, latihan beban juga dapat meningkatkan performa olahraga seperti sepak bola, bola basket, football, dan lain-lain. Tetapi, karena latihan beban penggunaannya secara repetitif, maka potensial untuk terjadinya cedera pada jaringan lunak. Penelitian ini bertujuan untuk mengetahui lokasi tersering cedera pada latihan beban. Penelitian ini menggunakan 94 orang sebagai responden yang dipilih secara simple random sampling, berusia antara 17-45 tahun dan merupakan anggota dari Body Fitness, Jakarta Barat. penelitian ini menggunakan Nordic Body Map Questionaire untuk mengetahui lokasi keluhan muskuloskeletal pada responden. Hasil penelitian ini menunjukkan regio punggung bawah atau pinggang adalah lokasi dengan keluhan muskuloskeletal tersering dan disusul oleh bahu, lutut, lengan atas, pergelangan tangan, dan leher.
\end{abstract}

Kata kunci : latihan beban, keluhan muskuloskeletal, punggung bawah

\section{Musculoskeletal Pain on Weight Training at Fitness Center 2017}

\begin{abstract}
Resistance training is a form of physical exercise that can increase endurance and muscle strength. In addition to increasing muscle strength, resistance training can also increase sport performance such as in soccer, basketball, football, etc. Unfortunately, because of the repetition in resistance training, it may potentially injure the soft tissues. The purpose of this research is to find out the most frequent locations of injuries in resistance training. This research used 94 people between 17-45 years of age as respondents which was chosen by simple random sampling among members of Body Fitness West Jakarta. This research used a Nordic Body Map Questionaire to locate musculoskeletal pain in resistance training. The results of this study showed that lumbal region was the most frequent musculoskeletal pain location in resistance training, followed by shoulders, knees, arms, hand wrist, and neck.
\end{abstract}

Keywords: resistance training, musculoskeletal pain, lumbal region 


\section{Pendahuluan}

Resistance training atau latihan beban merupakan sebuah bentuk latihan fisik yang dapat membantu meningkatkan daya tahan dan kekuatan otot. Berbagai macam pelatihan yang ada dalam latihan beban adalah latihan tanpa mesin (barbel dan dumbel), dengan mesin, karet elastis, bola untuk latihan kesehatan, dan gerakan-gerakan eksplosif untuk mengembangkan kekuatan otot. ${ }^{1}$ Dari penelitian, pada remaja dan anak-anak yang melakukan latihan beban dan mengikuti pedoman latihan sesuai dengan umur, termasuk pengawasan yang berkualitas, indikasi untuk cedera relatif rendah. ${ }^{2}$ Berbagai variasi program latihan beban dari sesi singleset pada mesin sampai protokol multi-set yang menggunakan perlengkapan yang beragam, telah terbukti aman dan bermanfaat. Peningkatan intensitas yang signifikan tanpa laporan cedera telah dilaporkan dalam studi prospektif, dimana gerakan weightlifting (termasuk menarik dan mendorong) digabungkan dalam program latihan beban remaja. $^{3}$

Selain menjadi lebih kuat, latihan beban juga dapat dilakukan untuk meningkatkan performa olahraga terkait (sepak bola, basket, football), mencegah cedera, rehabilitasi cedera, dan meningkatkan kesehatan jangka panjang. Sama seperti aktivitas fisik lainnya, latihan beban telah menunjukkan efek menguntungkan pada beberapa pengukuran kesehatan, seperti kardiovaskular, komposisi tubuh, kepadatan mineral tulang, profil lipid darah, dan kesehatan mental. Berlaku untuk semua umur, latihan beban menstimulasi mineralisasi tulang dan memberikan efek yang positif pada densitas tulang. ${ }^{4}$ Sudah sejak lama organisasi profesional memfokuskan pedoman latihan pada ketahanan dan latihan aerobik untuk menurunkan berat badan dan mempertahankannya, bahkan pedoman terbaru menyimpulkan latihan beban juga efektif untuk menurunkan massa lemak. ${ }^{5}$

Potensi untuk cedera pada jaringan lunak, karena penggunaannya secara repetitif merupakan pertimbangan penting berkaitan dengan latihan beban. Pada evaluasi terbaru cedera weightlifting (termasuk cedera latihan beban), dilaporkan bahwa bagian pinggang atau punggung bawah adalah bagian yang tersering cedera pada laki-laki (36.9\%) dan wanita (27.4\%) antara umur 14 dan 30 tahun. $^{6}$ Selain itu, ada laporan lain mengatakan bahwa regio punggung bawah merupakan bagian tersering yang mengalami cedera pada atlet dewasa yang berpartisipasi pada program latihan beban. Pada sebuah studi retrospektif yang melibatkan orang dewasa pengangkat beban, 50\% dilaporkan cedera pada punggung bawah. Rata-rata latihan orang dewasa tersebut 4.1 kali per minggu dengan 99 menit per sesi, dan sebagian besar sesi latihannya tanpa pengawasan dari pelatih. ${ }^{1}$ Tetapi, ada juga laporan bahwa bahu merupakan tempat yang paling sering mengalami cedera $(36 \%)^{7,8}$, diikuti dengan regio lumbal (24\%), bagian siku (11\%), dan lutut (9\%). ${ }^{7}$

\section{Metodologi Peneltitian}

Penelitian ini didesain deskriptif dalam rancangan cross-sectional untuk mendapatkan gambaran keluhan muskuloskeletal pada orang yang latihan beban di pusat kebugaran Body Fitness, Kebon Jeruk, Jakarta Barat pada tahun 2017. Pendekatan yang dipilih adalah secara simple random sampling dengan responden 94 responden yang memenuhi syarat penelitian antara lain; merupakan anggota Body Fitness, bersedia untuk dijadikan subjek penelitian, berusia 17-45 tahun, ada pada saat pengambilan responden, dan tidak hamil. Data diperoleh melalui Nordic Body Map Questionaire yang telah dimodifikasi, semua subjek akan diminta persetujuan (informed consent) secara lisan dan setelah itu mengisi kuesioner. Pengambilan data dilaksanakan setelah lolos kaji etik dengan nomor pengajuan375 / SLKE-IM / UKKW / FK / KE /1/ 2018. Pengolahan data dilakukan dengan menggunakan Microsoft Word 2016, Microsoft Excel 2016, dan SPSS (Statistical Product and Service Solutions) versi 22.0.

\section{Hasil Penelitian}

Penelitian ini dilakukan pada 94 responden pada periode 25 November - 2 Desember 2017. Pengambilan responden menggunakan simple random sampling dengan cara memasukkan data ke program www.miniwebtool.com. Dari seluruh data yang diambil didapatkan hasil sebagai berikut (lihat Gambar 1 s.d. 7). 


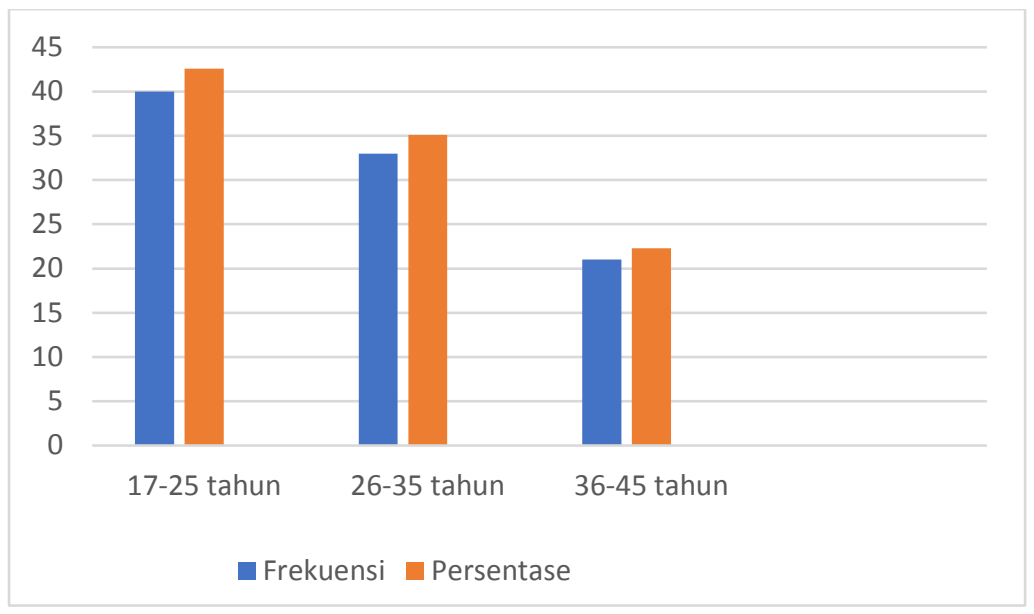

Gambar 1. Sebaran Umur Responden

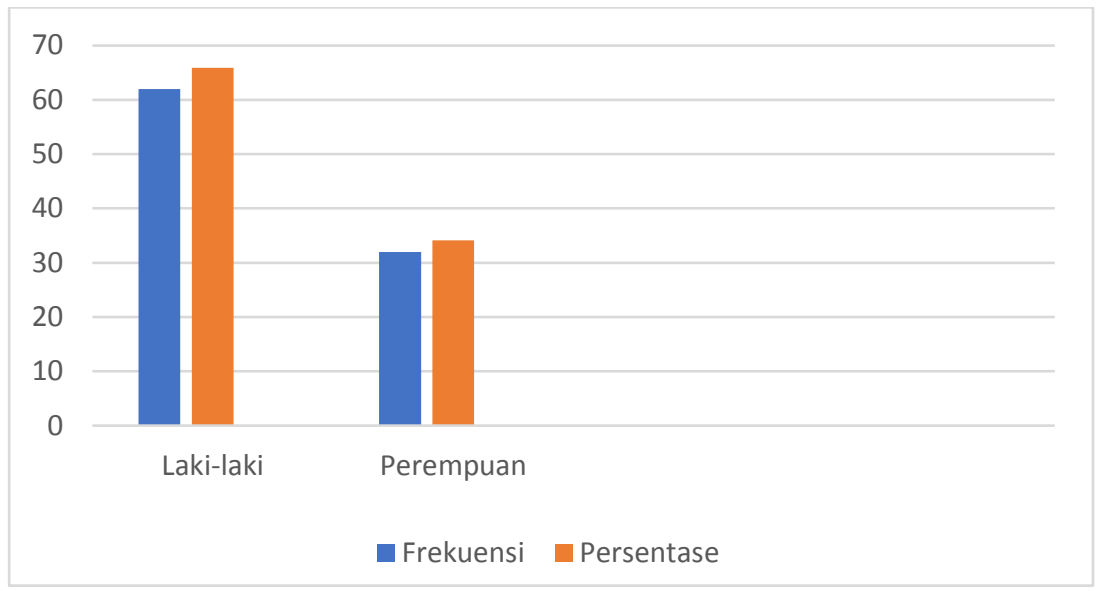

Gambar 2. Sebaran Jenis Kelamin Responden

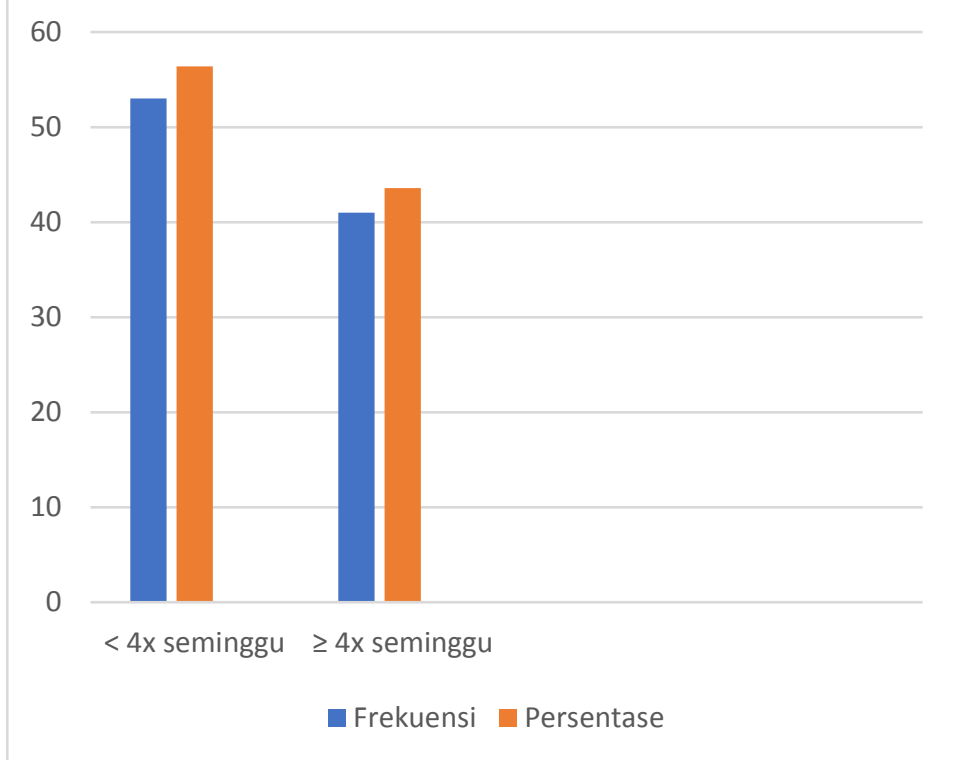

Gambar 3. Sebaran Rutinitas Latihan Responden 


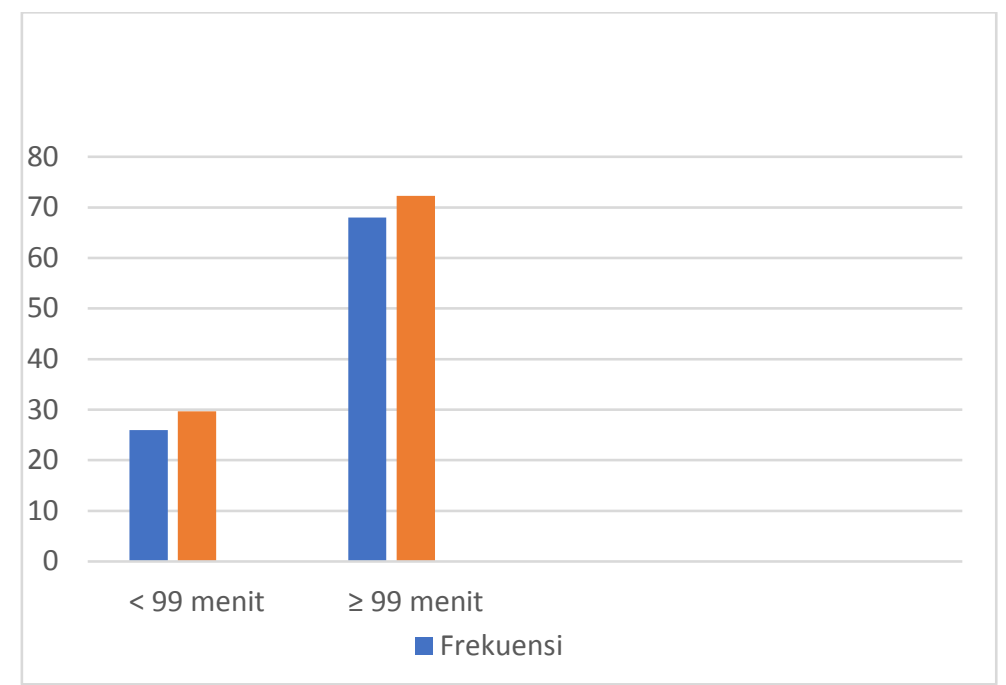

Gambar 4. Sebaran Lama Latihan Responden

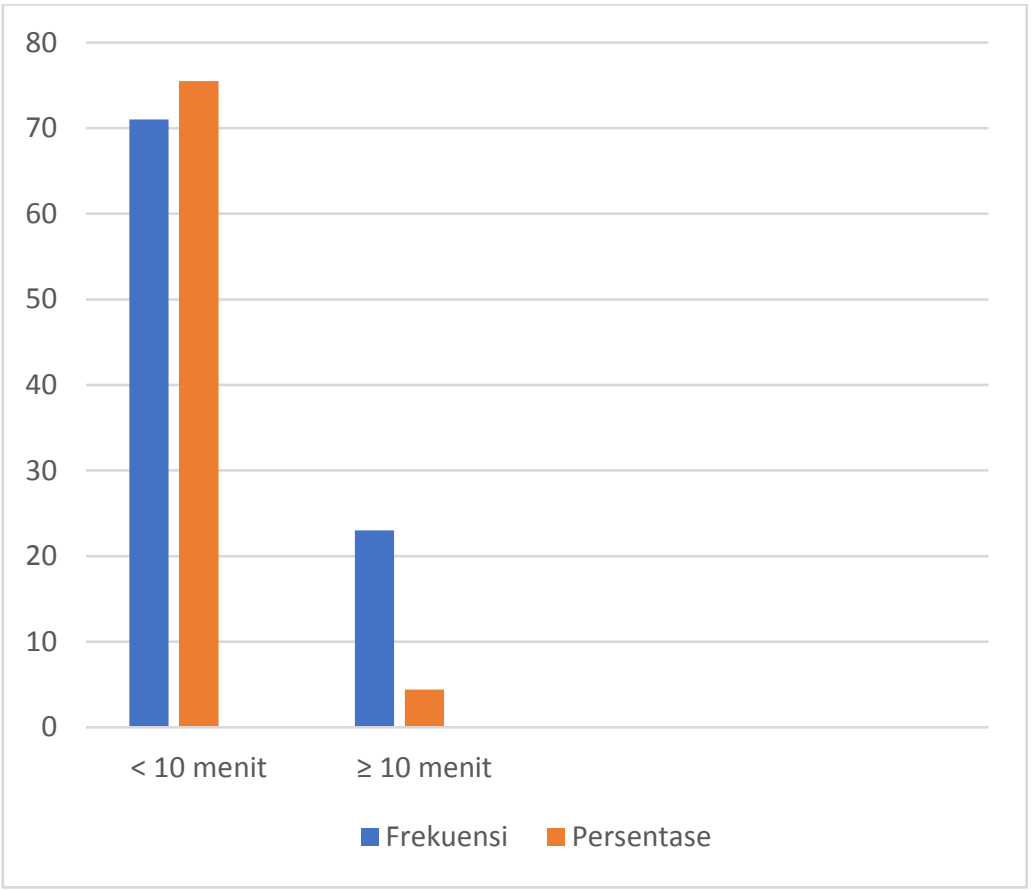

Gambar 5. Sebaran Lama Pemanasan Responden 


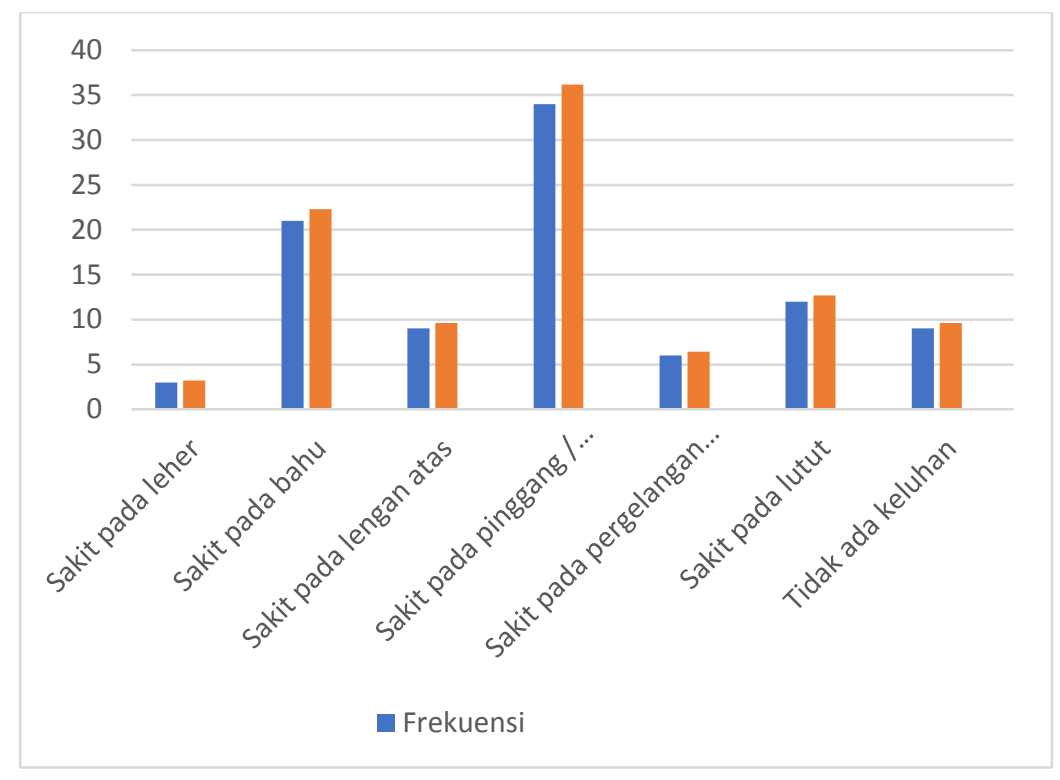

Gambar 6. Sebaran Jenis Keluhan Responden

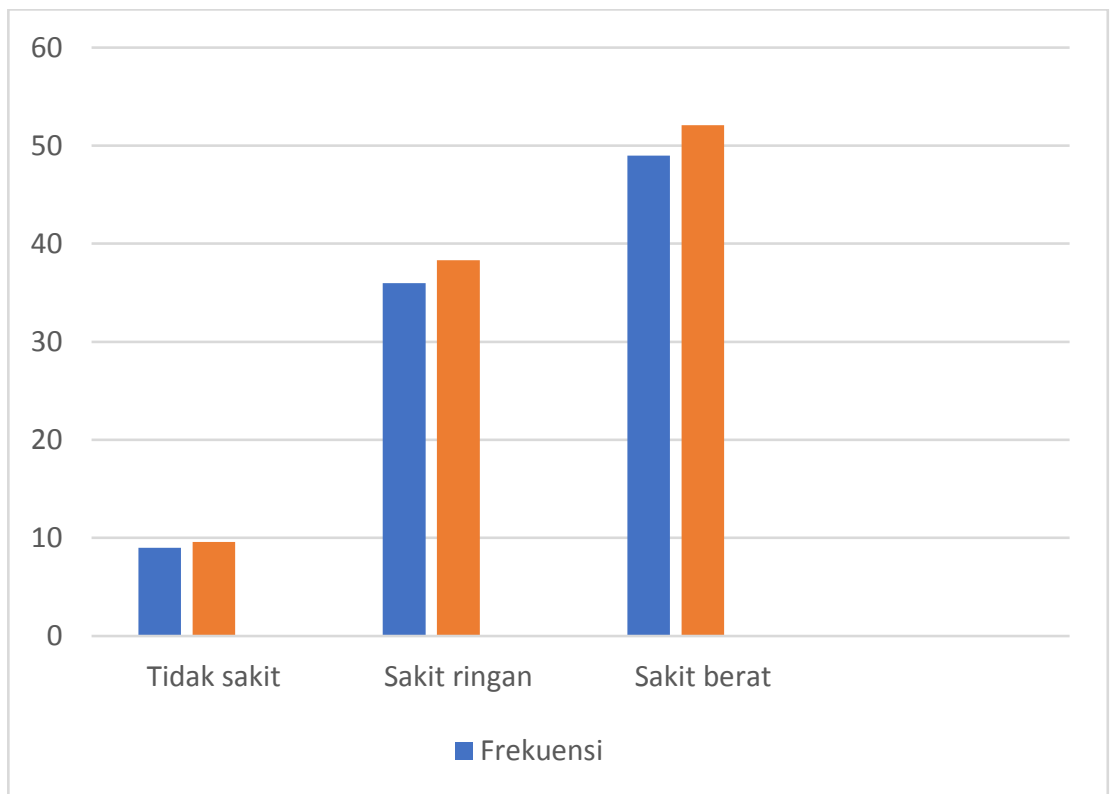

Gambar 7. Sebaran Derajat Sakit Responden

Berdasarkan hasil penelitian, didapatkan laki-laki 62 orang (65.9\%) dan perempuan 32 orang $(34.1 \%), 34$ orang $(36.2 \%)$ memiliki keluhan lokasi keluhan di pinggang atau punggung bawah, 21 orang $(22.3 \%)$ memiliki keluhan di bahu, 12 orang $(12.7 \%)$ memiliki keluhan di lutut, 9 orang $(9.6 \%)$ memiliki keluhan di lengan atas, 6 orang (6.4\%) memiliki keluhan di pergelangan tangan, 3 orang $(3.2 \%)$ memiliki keluhan di leher, 9 orang $(9.6 \%)$ dari total responden tidak memiliki keluhan, sehingga dari hasil penelitian ini didapatkan pinggang atau punggung bawah merupakan lokasi paling sering cedera, diikuti bahu, lutut, lengan atas, pergelangan tangan, dan leher. Hasil penelitian ini sejalan dengan penelitian yang dilakukan oleh Quatman, et al pada unit gawat darurat di Amerika Serikat, dilaporkan bahwa bagian punggung bawah dan pinggang merupakan lokasi paling sering terjadi cedera pada latihan beban, laki-laki (36.9\%) dan perempuan (27.4\%). Selain itu, hasil penelitian ini juga sejalan dengan Quatman, Fagenbaum, dan Myer yang dalam jurnalnya mengatakan bahwa pada studi retrospektif yang dilakukan pada orang dewasa yang latihan beban, didapatkan $50 \%$ cedera pada punggung bawah. 
Cedera punggung bawah merupakan cedera nonkontak yang disebabkan bukan karena trauma melainkan umumnya karena overuse. Penggunaan otot berlebihan dapat digambarkan dari lama latihan responden yang didominasi oleh $\geq 99$ menit dan rutinitas latihan.

Pada penelitian yang dibuat oleh Keogh, Hume, dan Pearson tentang studi retrospektif cedera pada 100 orang pengangkat berat di Oceania menyatakan bahwa bahu merupakan lokasi yang paling sering cedera. Selain itu penelitian yang dibuat oleh Siewe, Rudat, dan yang lainnya tentang cedera dan sindroma penggunaan berlebih pada pengangkat berat juga menyatakan bahwa bahu merupakan lokasi yang paling sering cedera. Tentunya, hasil yang dilakukan oleh para peneliti ini berbeda dengan data yang didapat, yaitu lokasi yang paling sering mengalami cedera terdapat di punggung bawah atau pinggang. Perbedaan hasil ini dapat diakibatkan dari perbedaan fokus kekuatan yang dilakukan. Latihan kekuatan yang diteliti oleh para peneliti tersebut merupakan angkat berat (powerlifting) sedangkan dalam penelitian ini merupakan latihan beban. Walaupun keduanya merupakan latihan kekuatan, tetapi jenis latihannya berbeda, sehingga lokasi yang paling sering cedera juga berbeda.

Dari penelitian ini, hanya didapatkan sembilan orang yang tidak memiliki keluhan, sedangkan terdapat 85 orang yang memiliki keluhan muskuloskeletal di berbagai lokasi antara lain, Punggung bawah, bahu, lutut, lengan atas, pergelangan tangan, dan leher. Hal ini dapat disebabkan karena kurangnya waktu pemanasan, teknik pada saat latihan beban yang salah, tidak melakukan pendinginan, waktu latihan yang lebih lama pada umumnya, dan rutinitas latihan. Kurangnya waktu pemanasan akan mengakibatkan otot belum sepenuhnya siap untuk latihan beban. Teknik pada latihan beban yang salah akan meningkatkan risiko cedera. Pendinginan merupakan hal yang penting untuk dilakukan setelah berolahraga, sehingga apabila tidak melakukan pendinginan akan meningkatkan faktor risiko nyeri muskuloskeletal. Waktu latihan yang lebih lama tentu akan mengakibatkan kelelahan otot sehingga otot menjadi lebih rentan. Latihan dengan frekuensi yang tinggi akan mengakibatkan kerusakan pada jaringan, otot yang mengalami kerusakan tidak dapat beregenerasi secara baik sehingga akan mengakibatkan meluasnya kerusakan jaringan dan menimbulkan keluhan. Selain itu, faktor risiko keluhan muskuloskeletal meningkat ketika otot yang digunakan berjalan melewati dua sendi atau tulang.

\section{Kesimpulan}

Gambaran keluhan muskuloskeletal pada orang yang latihan beban di Body Fitness didapatkan hasil sebagai berikut; kelompok dengan umur terbanyak adalah usia 17-25 tahun ditemukan sebanyak 40 orang, jenis kelamin terbanyak adalah laki-laki ditemukan sebanyak 62 orang, rutinitas latihan terbanyak adalah < 4x seminggu sebanyak 53 orang, lama latihan terbanyak adalah $\geq 99$ menit sebanyak 68 orang, lama pemanasan terbanyak adalah $<10$ menit sebanyak 71 orang, jenis keluhan terbanyak adalah sakit pada pinggang atau punggung bawah sebanyak 34, derajat sakit terbanyak adalah sakit berat sebanyak 49 orang. Mengingat peneliti hanya mencari lokasi tersering yang mengalami keluhan muskuloskeletal, penelitian ini perlu diperkuat dengan mencari jenis keluhan muskuloskeletal tersering pada latihan beban.

\section{Daftar Pustaka}

1. Faigenbaum AD, Myer GD. Resistance training among young athletes: safety, efficacy, and injury prenvention effects. Br J Sports Med. 2010 Jan; 44(1): 56-63.

2. Malina R. Weight training in youth growth, maturation and safety: an evidenced based review. Clin J Sports Med. 2006;16:478-87.

3. Channell BT, Barfield JP. Effect of Olympic and traditional resistance training on vertical jump improvement in high school boys. J Strength Cond Res. 2008;22:1522-7.

4. McCambridge TM, Stricker PR. Strength Training by Children and Adolescents. Pediatrics. 2008 Apr; 121(4): 835.

5. Donnelly JB, SN, Jakicic JM, Manore MM, Rankin JW, Smith BK. Appropriate Physical Activity Intervention Strategies for Weight Loss and Prevention of Weight Regain for Adults. Med Sci Sports Exerc 2009;41: 459-71. 
6. Quatman C, Myer G, Khoury J, et al. Sex differences in "weightlifting" injuries presenting to United States emergengy rooms. J Strength Cond Res. 2009 23:2061-7.

7. Keogh J, Hume PA, Pearson S. Retrospective injury epidemiology of one hundred one competitive Oceania power lifters: The effects of age, body mass, competitive standard, and gender. J Strength Cond Res. 2006; 20:672-81.

8. Siewe J, Rudat J. Injuries and overuse syndromes in powerlifting. Int $\mathrm{J}$ Sports Med 2011; 32:703-11. 